pp. $77-87$

Justyna MIELNIK

ORCI: 0000-0002-4523-3698

Uniwersytet Pedagogiczny im. KEN w Krakowie

\title{
Dziecko konsumentem internetu
}

\section{Abstract: A Child is an Internet's Consumer}

We live in very strange times. Dynamic changes are taking place in front of our eyes. Every day, new, innovative devices, programs and software are created. The world has sped up and people have to adapt to it in the best way possible. Being able to filter so much information is not easy for adults, and even harder for children that are just learning everything. Therefore, it is worth asking yourself whether everything that the world gives us is good, and if not, can we see it? If so, can we protect children from the negative effects of new media and modern technology and teach them to use wisely the benefits of today?

The article describes the media, their importance in the modern world and their split. Social media, which are currently considered one of the greatest achievements of mankind, as well as the Internet, where its functions, advantages, but also the dangers it brings are presented in more detailed way. Television, which plays an important role in family life, is also described in this work. The next chapter presents the results of the own research. During the interviews, the students answered questions about what electronic devices they use most often, what websites they use most often, what time they spend in front of the screen/on the Internet and if they know the dangers of using the Internet. In addition, during the study, students' knowledge of the advantages of using the Internet was tested, why they use internet and how people using internet are controlled.

The conclusions of this study are varied.

What is the most importantly, we still don't know exactly how to keep children protected from modern media. Among parents and teachers there is a lot of missing knowledge. It is important to educate teachers, parents but as well children about that. All this can help us to ensure that young people, as well as adults, will only the benefits from what the modern world offer them.

Keywords: media, modern technology, electronic equipment, internet, social media, television, threats

Słowa kluczowe: media, nowoczesna technologia, sprzęty elektroniczne, internet, social media, telewizja, zagrożenia 


\section{Wprowadzenie}

Długo zastanawiałam się nad tematem pracy, który ma dotyczyć konkretnego problemu współczesnej pedagogiki wczesnoszkolnej. Uważam, że można zająć się tu wieloma ciekawymi kwestiami, czasy, w jakich żyjemy, są jednak bardzo specyficzne. W ostatnich latach nasz świat przyspieszył, a nowa technologia stała się jego królową. Kartkę papieru zastąpiła klawiatura telefonu czy też komputera. Z tym wszystkim teraz muszą zmierzyć się dzieci. Nie jest to łatwe, gdyż młode osoby nie zdążyły jeszcze krytycznie spojrzeć na to, co oferuje im świat. Dlatego też zdecydowałam się zajać tematem, który brzmi: „Dziecko konsumentem internetu". Po przeprowadzeniu badań i zapoznaniu się z literaturą na ten temat utwierdziłam się w przekonaniu, jak jest on ważny. Poniżej postaram się przytoczyć najważniejsze informacje, które udało mi się odnaleźć, a także odniosę je do wyników, które otrzymałam podczas swoich badań.

W naszych czasach panuje elektronika i internet. W bardzo krótkim czasie stały się one nieodzownym elementem życia każdej polskiej rodziny. Często zastanawiamy się nad tym, czy świat, w którym przyszło nam żyć, jest dobry. Wielokrotnie miałam możliwość usłyszeć od starszych pokoleń, że dawniej było lepiej. Dzieci spędzały więcej czasu na zewnątrz, dzięki czemu uczyły się odpowiednich zachowań, nawiązywały dużo więcej nowych znajomości. Zarówno one, jak i dorośli mieli więcej ruchu, który, niestety, aktualnie często jest zaniedbywany. Uwaga ludzi teraz jest skupiona przede wszystkim na telefonach, komputerach $i$ innych sprzętach elektronicznych. Oczywiście, możemy tak narzekać w nieskończoność, lecz w moim odczuciu powinniśmy po prostu przyjąć, że czasy się zmieniły, i nauczyć się mądrego korzystania z tego, co zostało nam dane.

\section{Znaczenie mediów we współczesnym świecie}

Na samym początku pragnę zając się krótkim omówieniem podstawowych teoretycznych zagadnień. Zacznę od tego, czym właściwie są media. Samo słowo pochodzi z języka łacińskiego i oznacza punkt pośredni, środek. Jest to pojęcie bardzo szerokie, a także niejednoznaczne. Ważne jest to, że znaczenie tego słowa $\mathrm{z}$ biegiem czasu się poszerza. Media odgrywają istotną rolę w życiu ludzi, gdyż nie tylko kształtują ich poglądy, ale także próbują im narzucić podejście do świata (Frania, 2017, s. 49). Media można podzielić na stare i nowe. To rozgraniczenie funkcjonuje głównie w kontekście cyfryzacji, gdyż właśnie pojawienie się zapisu cyfrowego było wydarzeniem przełomowym, łącząc nowe media z komputerem (Konik, 2016, s. 24). Do nowych mediów zaliczamy m.in. zeskanowaną fotografię obrazu olejnego z XIV w., przekonwertowany na nośnik cy- 
frowy film z początku XX w., jak również animację, która została stworzona za pomocą programów graficznych przy użyciu komputera. Dlatego też początku nowych mediów można dopatrywać się w fotografii (s. 25). Musimy zdawać sobie sprawę, że media przeszły i nadal przechodzą ogromną metamorfozę. Jest to proces ciągły, a $\mathrm{z}$ biegiem czasu stare media płynnie przekształciły się w nowe (s. 52).

Monika Frania (2017) w swojej książce do nowych mediów zalicza: blogi, YouTube, Wikipedię, Digg, Myspace, Facebook, Twitter, Second Life, a także podcasty. Istotne jest to, że wszystkie te media mają charakter społecznościowy.

Społeczeństwo ma obecnie bardzo łatwy dostęp do informacji. Dawniej, aby odnaleźć wiadomości na konkretny interesujący nas temat, musieliśmy iść np. do biblioteki czy też kupić książkę. Wertowaliśmy książkę tak długo, aż odnaleźliśmy szukane informację. Aktualnie nasza rzeczywistość wygląda całkiem inaczej. Kiedy chcemy się czegoś dowiedzieć, sięgamy po telefon czy też siadamy przed komputerem i przeszukujemy internet. Zdaniem M. Frani (2017) dzisiejsze społeczeństwo można określić jako sieciowe, informacyjne i cyfrowe. Świat, w którym żyjemy, można nazwać cywilizacją medialną. Nowe technologie i media towarzyszą ludziom już od narodzin. Idąc dalej tym tropem, warto zauważyć, że nowe media odgrywają również ważną rolę w edukacji. M. Frania (2017) wyraźnie mówi, że obecna edukacja jest coraz bardziej wirtualna, czyli globalna, lokalna, technologiczna, hipermedialna, kulturowa i pozainstytucjonalna. Dodatkowo autorka ta podkreśla, że edukacja jest w coraz większym stopniu zdominowana przez media, które są rozumiane w sposób wieloznaczny, o czym pisałam już nieco wcześniej. To, że media się ciągle zmieniają, rozwijają i przeobrażają, powoduje, że zmianie ulegają treści nauczania, ale także zmian można dopatrywać się w relacjach nauczyciel-uczeń czy też rodzic-dziecko.

Podziału mediów można dokonać według ich oddziaływania, możemy więc wyróżnić media pośrednie i bezpośrednie. Te pierwsze są obecne w życiu człowieka podczas codziennych czynności, takich jak rozmowy, spacer, czytanie, i wypełniają około 25 godzin tygodniowo (Rostowska, Jarmołowska (red.), 2010, s. 23). Do tych oddziaływań można dodać przejmowanie od innych opinii, które zostały ukształtowane przed media. Oddziaływanie bezpośrednie to nic innego, jak wpływ odbieranych treści. Skutek tego oddziaływania jest zależny od treści przekazu, cech odbiorcy, nadawcy i używanego medium.

Dzieciństwo jest okresem, w którym następuje kształtowanie się osobowości i postaw. Właśnie w tym czasie jednostka jest najbardziej podatna na oddziaływanie mediów. Istotna jest także forma przekazu. Na przykład radio charakteryzuje się jednostronnością nadawania i biernością odbiorcy. Inne media wymagają natomiast aktywności odbiorcy, a co za tym idzie - nie powodują bierności (s. 24). 


\section{Social media jako jeden z największych wynalazków ludzkości}

Mówiąc o mediach, koniecznie trzeba wspomnieć o mediach społecznościowych, czyli o social mediach. Pewnie każdy się zgodzi ze stwierdzeniem, że są one jednym z największych wynalazków ludzkości (Gawrol, 2016, s. 55). Social media można definiować jako środek przekazu podlegający społecznej kontroli. Zawiera on treści przekazu i różne punkty widzenia odnoszących się do przeróżnych informacji (Sala, Królewski, 2016, s. 157). Wśród mediów społecznościowych należy wyróżnić sześć typów (Grębosz, Siuda, Szymański, 2016, s. 1718): blogi, portale społecznościowe, projekty zbiorowe, społeczności skupione wokół treści, wirtualne światy społeczne i wirtualne gry. Mówiąc o portalach społecznościowych, należy podkreślić ich korzyści. Umożliwiają one ludziom zawieranie nowych znajomości w bardzo prosty sposób, dodatkowo pozwalają utrzymywać stały kontakt $\mathrm{z}$ innymi użytkownikami. Media społecznościowe mimo wielu pozytywnych aspektów niosą również zagrożenia, o których również za chwile wspomnę.

Pisząc pracę licencjacką, dotarłam do ciekawych badań dotyczących sposobu spędzania czasu wolnego przez uczniów (Wawrzonkiewicz-Słomska, Cholewa, 2017, s. 28). Ich wyniki wyraźnie pokazały, że mimo iż na pierwszym miejscu znajdywało się „uprawianie sportu”, to na drugim miejscu, czyli także „na podium”, znalazło się korzystanie z mediów. Jest to dowód na to, jak ogromną rolę media odgrywają już w dzieciństwie.

Anna Wawrzonkiewicz-Słomska i Ewelina Cholewa (2017, s. 28) zaprezentowały również w swoim artykule tabelę, która przedstawiała listę najpopularniejszych mediów wśród uczniów. Bezapelacyjnie pierwsze miejsce zajął internet. Nieco dalsze miejsce zajęła telewizja. Te wyniki również odzwierciedlają realia. Świat, w którym żyjemy, opanowany jest przez media. Książki papierowe zostały zamienione na elektroniczne. Wszystko, co nas otacza, powoli zmienia swoją formę na wirtualną.

Media, jak już wspomniałam, są nośnikiem mnóstwa informacji, do których łatwo mogą dotrzeć ludzie. Aby media mogły wpływać w sposób pozytywny na odbiorców, treści przekazu powinny być odpowiednio dobrane do wieku i etapu rozwoju danej jednostki. Tutaj warto podkreślić rolę rodziców, opiekunów i nauczycieli. A. Wawrzonkiewicz-Słomska i E. Cholewa (2017) w swojej książce wspominają o bardzo ciekawym badaniu, które zostało przeprowadzone pod koniec lat sześćdziesiątych XX w. Dotyczyło one pozytywnego wpływu telewizji na dzieci. Grupę badawczą stanowiły dzieci w wieku 3-5 lat. Okazało się, że te, które oglądały programy edukacyjne, były lepiej przygotowane do rozpoczęcia nauki szkolnej, odznaczały się zdecydowanie wyższym poczuciem wartości i osiągały lepsze wyniki w nauce. Podczas badań okazało się jednak również, że telewizja wpływa w bardzo małym stopniu na kreatywność dzieci i że większą 
skuteczność w tym zakresie mają radio czy też media drukowane. Tutaj warto wspomnieć o e-learningu, który umożliwia nauczanie na odległość dzięki platformie internetowej.

\section{Znaczenie telewizji w życiu rodzinnym}

Tu powiemy nieco więcej o telewizji, która jest jednym $z$ najpopularniejszych mediów. Joanna Kata (2017) w swojej książce zauważa, że kontakt dzieci z mediami, a więc także z telewizją, często rozpoczyna się bardzo wcześnie. Czas, który dzieci spędzają przed telewizorem, nie jest normowany i stopniowo się wydłuża. Niestety, obecnie pojawił się problem związany z nieodpowiednim korzystaniem przez dzieci z mediów. Chodzi tu przede wszystkim o nieprzeznaczonedla nich treści czy też zbyt długi czas spędzany przed ekranem. Okuliści, ortopedzi czy neurologowie biją na alarm. Dziecko spędzające zbyt długi czas przed ekranem automatycznie narażone jest na wiele niepożądanych schorzeń (zapalenie spojówek, gwałtowne zaniki ostrości widzenia, zmiany w postrzeganiu barw etc.). Dodatkowo telewizja ogranicza czas spędzany przez dzieci na świeżym powietrzu (Kata, 2017, s. 68-69).

W wielu rodzinach telewizor jest nieodzownym elementem życia. Niektórzy budzą się rano, wchodzą do kuchni i niemal automatycznie włączają telewizor. Wspólnie jedząc śniadanie, kątem oka zerkają na różne treści wyświetlane na ekranie. Dodatkowo telewizor „pomaga” rodzicom w trudniejszych momentach, kiedy muszą wykonać jakąś ważną czynność i zająć czymś uwagę swoich pociech. Dochodzi tu do „zatrudnienia” telewizora w charakterze „toksycznej niani”. Wydaje się, że część rodziców nie ma świadomości, że ich rola nie kończy się na nauczeniu dzieci obsługi telefonu czy komputera. Ich zadaniem jest również nauczenie ich mądrego korzystania $\mathrm{z}$ tych sprzętów i selektywnego korzystania z programów telewizyjnych (Kata, 2017, s. 70). Niestety, zbyt długie oglądanie telewizji przez dzieci może powodować u nich: ból głowy wskutek promieniowania elektromagnetycznego, garbienie się, zmniejszoną aktywność fizyczną czy nawet brak chęci do podejmowania zadań, które wymagają wysiłku intelektualnego (s. 75-76). Dziecko może popaść w rodzaju transu, podczas którego nie może nawiązać aktywności ruchowej. Dodatkowo zbyt duża ilość informacji może spowodować, że dziecko się zagubi i zostanie narażone na zaburzenia rozwoju myślenia.

Ponieważ telewizja jest dostępna dla każdego dziecka i nie da się przed nią po prostu uciec, konieczne jest, aby dzieci potrafiły mądrze $z$ niej korzystać, umiały oddzielić świat prawdziwy od nierealnego i zdawały sobie sprawę z zagrożeń związanych ze zbyt długim oglądaniem programów i niewłaściwym doborem treści. 


\section{Internet - najważniejsze medium współczesnych czasów}

Internet jest jednym z najważniejszych mediów XXI w., dlatego też obowiązkowo muszę o nim wspomnieć. Internet jest to zespół komputerów razem z urządzeniami peryferyjnymi, które są połączone za pomocą linii transmisji danych. Zadaniem tych linii jest łączenie komputerów na całym świecie, dzięki czemu użytkownicy mogą się szybko ze sobą komunikować (Hofmokl, 2009, s. 63). Justyna Hofmokl (2009) uzupełnia przytoczoną definicję internetu, dodając, że jest on globalnym systemem komunikacji, a jego funkcjonowanie jest związane z zastosowaniem otwartych i niekomercyjnych standardów telekomunikacyjnych. Mówiąc o internecie, istotne jest wymienienie jego najważniejszych funkcji: rozrywkowej, komunikacyjnej, informacyjnej (daje możliwość pozyskania wiedzy ogólnej lub szczegółowej), edukacyjnej (wspomaganie wiedzy szkolnej) (Słysz, Arcimowicz, 2009, s. 17).

Nietrudno odgadnąć, że dla dzieci najważniejsza jest funkcja rozrywkowa. Poza tym istotne jest dla nich to, że w łatwy sposób mogą odnaleźć potrzebne $\mathrm{w}$ danym momencie informacje i że mają możliwość utrzymania stałych kontaktów z innymi użytkownikami. W tym miejscu pragnę wymienić podstawowe cechy komunikacji za pośrednictwem internetu: brak kontaktu fizycznego, anonimowość, płynność tożsamości, pokonywanie ograniczeń przestrzennych, dostępność wielu kontaktów, równość statusów ludzi wchodzących w kontakt itd. (s. 17-18). Z tego można wnioskować, że największym plusem, a zarazem minusem, jest to, że nie ma tutaj mowy o bezpośrednim kontakcie $z$ innymi. Każdy wie, że człowiek jest istotą społeczną, i potrzebuje bezpośrednich interakcji. Kontakt fizyczny odgrywa tu wielką rolę. W internecie bardzo łatwo można ukryć swoją prawdziwą tożsamość, udając kogoś, kim w rzeczywistości się nie jest. Młodzi ludzie niestety mają tendencje do dosyć szybkiego wyolbrzymiania pozytywnych cech internautów, co może przynieść w przyszłości przykre skutki.

Pragnę podkreślić, że internet to wspaniały wynalazek. Przynosi nam wiele dobrego, istotne jest jednak to, aby każdy człowiek potrafił rozsądnie go używać. Każdy powinien być świadomy jego wad i zalet, również dzieci. Dzięki temu będziemy w stanie uchronić je i siebie przed jego negatywnymi skutkami.

Dzieci, które korzystają z internetu bez kontroli dorosłych, są narażone na dotarcie do nieodpowiednich treści. Chodzi tu m.in. o pornografię, oszustwa, przemoc, nietolerancję czy też usługi, które mogą być dla nich niebezpieczne. Niestety, młode osoby dosyć łatwo mogą dokonać zakupu rzeczy czy produktów, które mogą zagrażać ich zdrowiu, a nawet życiu. W internecie można być anonimowym i udawać kogoś, kim się nie jest. Wykorzystują to ludzie, którzy nie mają dobrych zamiarów wobec dzieci. Dzieci nieświadomie mogą udzielić ważnych osobistych informacji, co może mieć bardzo przykre konsekwencje. 
Mogą stać się ofiarami oszustwa i wykorzystywania, ale - co najważniejsze mogą się uzależnić (Aftab, 2003, s. 84-85). Objawami uzależnienia jest obniżony poziom satysfakcji wynikający z korzystania $z$ internetu przez ograniczony czas. Konsekwencją tego jest wydłużanie czasu przebywania dzieci w sieci. Kolejnym symptomem jest zespół abstynencyjny, zmniejszenie bądź zrezygnowanie z innych aktywności (Barłóg, 2015, s. 198). Ważne jest to, aby każdy zdawał sobie sprawę, czym jest uzależnienie $\mathrm{i}$ jak chronić przed nim nie tylko dzieci, ale i siebie.

Mając na uwadze wszystkie zagrożenia wynikające $\mathrm{z}$ korzystania $\mathrm{z}$ internetu, powinniśmy znać sposoby na to, aby się przed nimi chronić. Parry Aftab (2003) wymienia kilka zasad, które mogą nam w tym pomóc: kontrolować czas spędzany przez dzieci przed komputerem; pamiętać, że komputery nie powinny zastępować realnych przyjaciół i kolegów; nie umieszczać komputera w pokoju dziecka. Istotna jest kontrola rodzicielska i dobry kontakt rodzica $\mathrm{z}$ dzieckiem. Rodzice powinni znać zainteresowania dzieci w sieci, a także uświadamiać im zagrożenia, jakie na nie czyhają.

Mając świadomość tego, jak ogromną rolę odgrywa internet i sprzęty elektroniczne $\mathrm{w}$ naszym życiu, postanowiłam przeprowadzić badania $\mathrm{w}$ tym zakresie. Moim głównym celem było przedstawienie zainteresowań dzieci treściami medialnymi. Przedmiotem badań były wypowiedzi dzieci na temat interesujących ich treści w internecie. Postawiłam pytanie główne: „Jakie treści budzą w internecie zainteresowanie dzieci?” Posłużyłam się metodą sondażową i techniką wywiadu. Niektóre osoby mogą się zastanawiać, dlaczego wybrałam taki sposób badania. Otóż nie zależało mi na liczbie osób badanych. Istotne było dla mnie to, aby porozmawiać z dziećmi, widzieć ich wyraz twarzy i postarać się wydobyć od nich jak najwięcej informacji. Często podczas wywiadów pojawiały się ciekawe zagadnienia, które nie wystąpiłyby podczas wypełniania ankiety.

\section{Badania własne}

W moim badaniu wzięło udział 17 uczniów. Dziewcząt było 11, natomiast chłopców 6. Badanymi byli uczniowie drugiej i trzeciej klasy podstawowej na wsi. Wiek uczniów to 8-10 lat. Dobór grupy był celowy, uzasadniony podjętym przeze mnie problemem badawczym.

Badanie przeprowadzałam na lekcjach, pod nadzorem wychowawców. Wywiady miały charakter indywidualny. Procedura badania była taka sama w obu klasach. Nauczyciel wskazał mi ławkę na końcu sali, gdzie pojedynczo podchodzili do mnie uczniowie. Reszta dzieci w tym czasie rozwiązywała zadane przez nauczyciela zadania. Każdy wywiad trwał 5-10 minut. Pytania, które zadawałam uczniom, były zgodne z kwestionariuszem wywiadu. Każda odpowiedź by- 
ła przeze mnie notowana. Niestety, nie otrzymałam zgody na nagrywanie wywiadów. Badanie było anonimowe, jedyne informacje, które były mi potrzebne, to: imię i wiek osoby badanej.

Niektóre odpowiedzi, które otrzymałam były dla mnie oczywiste, inne mnie zaskoczyły.

Na pytanie dotyczące tego, z jakich sprzętów elektronicznych korzystają uczniowie klasy drugiej i trzeciej, uzyskałam następujące odpowiedzi. Na pierwszym miejscu bezapelacyjne znalazł się telewizor. Częstym argumentem dzieci było to, że jest on włączony w domu przez cały dzień, co powoduje, że mimowolnie co jakiś czas dzieci spoglądają na niego i jeśli ich coś w danym momencie zainteresuje, to zaczynają oglądać. Kolejnym sprzętem wymienionym przez osoby badane był telefon. Niektórzy uczniowie tłumaczyli, że jest on tak lubiany przez nich, gdyż ma niewielkie rozmiary i wszędzie można z niego korzystać. Rzadziej wymieniano tablet i komputer.

Kolejny problem dotyczył stron i aplikacji, z których najczęściej korzystają uczniowie w internecie. Najczęstszą odpowiedzią uczniów była gra komputerowa. Wielu uczniów podkreśliła, że granie jest jedną z najbardziej lubianych aktywności relaksujących po zajęciach szkolnych. Równie często uczniowie korzystają z serwisu internetowego YouTube. Wykorzystują go do słuchania muzyki czy też oglądania bajek. Najrzadsze odpowiedzi uczniów dotyczyły aplikacji mobilnej Tik Tok i serwisu internetowego HBO GO.

Czas, jaki dzieci spędzają dzieci przed ekranem/w sieci, był kolejnym problemem badawczym. $Z$ odpowiedzi uczniów wynikało, że większość z nich może codziennie po szkole korzystać ze sprzętu. Duża część uczniów oświadczyła, że mają limity czasowe, które wynoszą od godziny do dwóch. Wśród badanych znalazły się osoby, które ze sprzętów mogą korzystać tylko w weekend, a także takie, których rodzice nie kontrolują czasu spędzanego przed komputerem oraz telewizorem.

Podczas wywiadu zapytałam uczniów o zagrożenia występujące podczas użytkowania internetu. W większości byli świadomi tych zagrożeń, co wynikało stąd, że w szkole były prowadzone zajęcia uświadamiające dzieci w tym zakresie. Dodatkowo uczniowie poinformowali mnie, że rodzice również rozmawiali z nimi na ten temat i uczyli mądrego korzystania $z$ tego środka przekazu. Zagrożenia, które zostały wymienione przez dzieci, to m.in.: oszustwa, uzależnienia, kradzieże i nawiązywanie niebezpiecznych kontaktów z obcymi osobami.

W odniesieniu do zagadnienia, które dotyczyło znajomości przez dzieci zalet korzystania $z$ internetu, większość badanych wymieniła możliwość nabycia nowych umiejętności, pisania książki, uczenia się języka obcego, a także pomoc w nauce i odrabianiu prac domowych. Nie było ucznia, który by nie wymienił chociażby jednej zalety. 
Jeśli chodzi o cele korzystania przez badanych z internetu, uczniowie wymienili najczęściej: naukę i sprawianie sobie przyjemności. Te odpowiedzi najczęściej padały łącznie.

Ostatnim zagadnieniem było sprawdzenie, jak wygląda kontrola dzieci podczas użytkowania internetu. Najczęściej badani odpowiadali, że w większym bądź w mniejszym stopniu ta kontrola występuje. Niektórzy uczniowie opowiadali, że jeden z rodziców co jakiś czas do nich podchodzi i sprawdza, co aktualnie robią. Dosyć częstą odpowiedzią było również stwierdzenie, że rodzice ich nie kontrolują. Badani twierdzili, że wynika to stąd, że mają oni do nich ogromne zaufanie.

\section{Wnioski}

Przeprowadzając wywiady z uczniami uczęszczającymi do drugiej i trzeciej klasy podstawowej, uzyskałam sporo odpowiedzi, które mnie zaskoczyły, zarówno pozytywnie, jak i negatywnie. Oczywiście, wiele informacji potwierdziło moje przypuszczenia, inne zaś spowodowały u mnie zmianę spojrzenia na dany temat.

Pierwszą sprawą są sprzęty, z których korzystają najczęściej uczniowie. Telewizor był na pierwszym miejscu. Jest to dosyć ciekawe, gdyż z rozmów z uczniami wywnioskowałam, że to, iż jest on najczęściej użytkowany, nie oznacza, że jest przez nich najbardziej lubiany. Chodzi raczej o to, że taki stan rzeczy jest wymuszany przez rzeczywistość rodzinną. Telewizor często jest po prostu włączony w tle, życie rodzinne toczy się natomiast obok niego. Innym powód może polegać na tym, że bardzo głośno mówi się o negatywnych skutkach korzystania z komputera, a telewizor nie jest w tym kontekście wymieniany. Dlatego rodzice/opiekunowie mogą nie zdawać sobie sprawy z zagrożeń płynących ze zbyt częstego korzystania $z$ tego sprzętu. Duża część uczniów wymieniła także telefon komórkowy jako sprzęt codziennego użytku, mały i wygodny w obsłudze. W dodatku dzieci bardzo często naśladują zachowania dorosłych, a — nie oszukujmy się — rodzice często nadużywają tego urządzenia. Spełnia ono funkcję komunikacyjną, informacyjną i rozrywkową. Uważam, że rodzice powinni uważniej podchodzić do tego tematu. Ważne są ograniczenia i kontrola.

Podczas wywiadów dowiedziałam się, że dla badanych najbardziej atrakcyjną rzeczą, jaką daje internet, jest możliwość grania. Ponieważ są to dzieci jeszcze małe, nie znają wielu innych zalet korzystania $\mathrm{z}$ sieci. Zaspokajają $\mathrm{w}$ ten sposób wrodzoną potrzebę zabawy.

Jeszcze niedawno świat wyglądał zupełnie inaczej. Dzieci wiele czasu spędzały na powietrzu, bawiąc się z rówieśnikami. Teraz potrzebę zabawy zaspakajają, siedząc przed komputerem i grając bądź oglądając bajki. Tutaj właśnie na- 
leży podkreślić ponownie rolę nie tylko rodziców, ale i nauczycieli. We wszystkim potrzebny jest umiar. Oczywiście, granie na komputerze czy oglądanie bajek nie jest niczym złym, jeśli odbywa się pod kontrolą dorosłych. Rodzice powinni kontrolować nie tylko treści, jakie przeglądają ich dzieci w sieci, ale także czas spędzany przed komputerem. Dobrym pomysłem jest określenie limitów czasowych. Niestety, żyjemy w świecie, gdzie internet jest wszechobecny. Większość rodziców korzysta z niego każdego dnia, co oczywiście widzą ich dzieci. Często dorośli nie zdają sobie sprawy z tego, jak dużą część ich dnia zajmuje im przeglądanie stron internetowych. Wręcz przeciwnie - zauważyć można, że część dorosłych nie widzi nic złego w codziennym spędzaniu przez dzieci czasu przed komputerem. Jest to związane zapewne $z$ brakiem wiedzy na ten temat. Myślę, że istotna jest tu edukacja zarówno dzieci, jak i dorosłych. Być może warsztaty na ten temat, przeprowadzane w szkołach przez wykwalifikowanych nauczycieli, mogłyby pomóc zrozumieć części rodziców zagrożenia płynące z niewłaściwego korzystania ze sprzętów. Ważne jest też to, aby i rodzice, i dzieci wiedzieli, jak bezpiecznie korzystać z internetu, jakie są jego wady i zalety. Moje badania pokazały, że taka świadomość u większości osób występuje. Istotną rolę odegrała tutaj szkoła, która starała się przygotować uczniów do tego, by mądrze podchodzili do tych kwestii. Uważam, że temat ten jest wciąż aktualny, i powinno się często do niego powracać.

Dzieci się ciągle uczą, więc warto pokazywać im szerokie możliwości internetu. Trzeba nauczyć je szybko odnajdywać potrzebne informacje, pokazywać strony, które mogą pomóc w nauce, ale także pokazywać gry, które mają walor edukacyjny. Bez tego dziecko nie będzie w stanie mądrze wykorzystać tego medium. Ostatnią rzeczą, którą uważam za bardzo ważną, jest kontrola rodzicielska.

Choć mamy zaufanie do naszych pociech, to zawsze powinniśmy mieć na uwadze ich bezpieczeństwo. Ludzie dorośli wielokrotnie wpadali za sprawą internetu w pułapkę. Nieraz słyszymy o tym, jak to ktoś został okradziony, oszukany. Jeśli dorośli mogą stać się ofiarami sieci, to tym bardziej mogą być nimi dzieci, które nie są świadome wielu niebezpieczeństw. Są z natury ufne. Ich osobowość się dopiero kształtuje, dlatego też łatwo nimi manipulować. Dlatego jeszcze raz powtarzam: kontrolujmy nasze dzieci.

\section{Zakończenie}

Żyjemy w czasach bardzo trudnych. Z jednej strony, mamy nieograniczony dostęp do informacji, a świat wirtualny stara się wyprzeć świat realny. Z drugiej strony, informacje nas przytłaczają. Nasz mózg każdego dnia walczy z milionem bodźców i wiadomości, które do niego napływają. Filtruje to wszystko, by po- 
zostawić tylko to, co najbardziej wartościowe. Nie zawsze mu się to jednak udaje. Dzieciom jest jeszcze trudniej. Ich mózgi się dopiero kształtują, dlatego są bardziej niż dorośli narażone na negatywne skutki dostępnych urządzeń. Oczywiście postęp technologiczny ułatwia ludzkie funkcjonowanie. Musimy sobie jednak zdawać sprawę, że wszystko ma swoje plusy i minusy. Wychowanie, ale także nauczanie, nigdy nie było łatwe. Od setek lat ludzi szukają sposobów na to, aby te procesy ulepszać. Wszechobecne media mogą pomóc pedagogom i rodzicom tylko wtedy, kiedy będziemy wiedzieć jak je mądrze wykorzystywać.

\section{Bibliografia}

Aftab, P. (2003). Internet a dzieci. Uzależnienia i inne niebezpieczeństwa. Przeł. B. Niecewicz. Warszawa: Prószyński i Sk-a.

Barłóg, M. J. (2015). Uzależnienie od internetu i jego osobowościowe determinanty. „Hygeia. Public Health", 50 (1), s. 197-202.

Frania, M. (2017). Nowe media, technologie i trendy w edukacji. Kraków: Impuls.

Gawrol, K. (2016). Portale społecznościowe — szanse i zagrożenia dla młodego człowieka. „Edukacja Technika - Informatyka”, 7, nr 2, s. 183-189.

Grębosz, M., Siuda, D., Szymański, G. (2016). Social media marketing. Łódź: Wyd. Politechniki Łódzkiej.

Hofmokl, J. (2009). Internet jako nowe dobro wspólne. Warszawa: Wyd. Akademickie i Profesjonalne.

Kata, J. (2017). Zagrożenia medialne i telewizyjne w gronie dzieci i młodzieży. „Nauczyciel i Szkoła”, 2, nr 62, s. 67-87.

Konik, R. (2016). Najnowsze nowe media i stare nowe media. Spór o definicje nowych mediów. „Dyskurs. Pismo Naukowo-Artystyczne ASP we Wrocławiu”, 22, s. 20-39.

Rostowska, T., Jarmołowska, A. (2010). Rozwojowe i wychowawcze aspektyżycia rodzinnego. Warszawa: Difin.

Sala, P., Królewski, J. (2016). E-marketing. Współczesne trendy. Pakiet startowy. Warszawa: PWN.

Słysz, A., Arcimowicz, B. (2009). Przyjaciele w internecie. Gdańsk: GWP.

Wawrzonkiewicz-Słomska, A., Cholewa E. (2017). Oddziaływanie mediów na dzieci i młodzież. „Problemy Współczesnej Pedagogiki”, 3, nr 1, s. 25-35. 